\title{
DIFFERENCES OF CULEX SPP AND AEDES SPP LARVAE MORTALITY RATES ON THE USE OF THEMEFOS
}

\author{
Wahyu Darmawan" ${ }^{1)}$ \\ ${ }^{1}$ Jurusan Kesehatan Lingkungan Poltekkes Kemenkes Jakarta II, Jl. Hang Jebat III, Jakarta \\ Selatan, 12120 \\ E-mail: darmawanwahyu19@gmail.com
}

Submitted: $21^{\text {th }}$ December 2020; Accepted: $6^{\text {th }}$ August 2021

https://doi.org/10.36525/sanitas.2021.9

\begin{abstract}
Eradication of the mosquito vectors that cause several diseases is still being carried out today where methods are still being developed. This research aims to identify the mortality rate of Culex spp. and Aedes spp. larvae for the use themefos or abate with sowed and wrapped of filter paper. The author uses quasi-experimental to observe that mortality. The design was devided into two groups, giving themepos/abate with a national dose of (1gr/10 liters of water) in 24 hours with threatment sowed and wrapped of filter paper through the analysis of varians/annova test to observe the varians of the time of mortality of Culex spp. and Aedes spp. larvae as well as probit analysis to see the probability of time of the larvae's death. The result of this research is no defference in the mortality of Culex spp. and Aedes spp. larvae for the uses of themefos/abate with sowed and wrapped of filter paper. The authors suggestion is giving themefos or abate by wrapping filter paper preverably for larvae in a stagnant water such as Aedes spp larvae because it does not provide residual granules in water reservoirs used for human activities while the used of themepos/abate with sowed can also be used for a stagnant water or has a small discharge.
\end{abstract}

Keywords: themepos, mosquito, larvae

This is an open access journal, and articles are distributed under the terms of the Creative Commons Attribution-Non Commercial-Share Alike 4.0 License, which allows others to remix, tweak, and build upon the work non-commercially, as long as appropriate credit is given and the new creations are licensed under the identical terms.

C2021 Sanitas 


\title{
PERBEDAAN ANGKA KEMATIAN JENTIK CULEX SPP DAN AEDES SPP PADA PENGGUNAAN THEMEFOS
}

\begin{abstract}
ABSTRAK
Pemberantasan vektor nyamuk penyebab berbagai penyakit masih terus dilakukan hingga saat ini dengan metode yang masih terus dikembangkan. Penelitian ini bertujuan untuk mengetahui angka kematian larva Culex spp. dan Aedes spp. untuk digunakan themefos atau abate dengan ditabur dan dibungkus kertas saring. Penulis menggunakan eksperimen semu untuk mengamati kematian tersebut. Rancangan dibagi menjadi dua kelompok yaitu pemberian themepos/abate dengan dosis nasional (1gr / 10 liter air) selama 24 jam dengan perlakuan ditabur dan dibungkus kertas saring melalui uji analisis varian / annova untuk mengamati varian waktu kematian larva Culex spp. dan Aedes spp. serta probit tes untuk melihat probabilitas waktu kematian larva nyamuk tersebut. Hasil dari penelitian ini adalah tidak ada perbedaan kematian Culex spp. dan Aedes spp. larva untuk penggunaan themefos/abate dengan tabur dan kertas saring. Saran penulis adalah pemberian themefos atau abate dengan cara kertas saring digunakan untuk larva di genangan air seperti larva Aedes spp karena tidak memberikan butiran sisa pada penampungan air yang digunakan untuk kegiatan manusia sedangkan penggunaan themepos/abate dengan tabur dapat juga dilakukan. untuk air yang tergenang atau memiliki debit yang kecil.
\end{abstract}

Kata kunci: themepos, jentik nyamuk

\section{PENDAHULUAN}

Kesehatan merupakan hal yang penting bagi setiap orang, seperti yang telah disebutkan dalam Undang-Undang RI nomor 36 tahun 2009 bahwa setiap orang berhak atas kesehatan, bahkan seseorang juga mendapatkan hak atas lingkungan yang sehat bagi pencapaian derajat kesehatan. Banyak hal yang menyebabkan kondisi kesehatan pada masyarakat berkurang, salah satunya penyakit yang terkait dengan lingkungan manusia.seperti penyakit yang ditularkan oleh vektor. Vektor yang sangat dekat dengan manusia diantaranya adalah nyamuk yang merupakan serangga yang mempunyai beberapa spesies yang sudah dibuktikan sebagai vektor penyakit.

Nyamuk merupakan serangga yang penting dibidang kesehatan karena peranannya sebagai vektor dari beberapa virus dan parasit. Salah satu cara untuk menekan populasi nyamuk adalah dengan memutuskan mata rantai kehidupannya. Salah satunya dengan pemberantasan larva yang merupakan kunci strategi program pengendalian vektor di seluruh dunia. Salah satu pengendalian yaitu penggunaan insektisida sebagai larvasida yang merupakan cara yang paling umum digunakan oleh masyarakat untuk mengendalikan pertumbuhan vektor tersebut. Insektisida yang sering digunakan di Indonesia adalah Abate (1). 
Abate (temephos) adalah larvasida sangat kuat yang secara efektif mengontrol fase larva (jentik) nyamuk sebagai penyebar penyakit yang penggunannya masih direkomendasikan oleh WHO melalui Kementerian Kesehatan yang secara nasional digunakan sebagai larvasida. Treatment yang dilakukan yaitu dengan menggunakan abate pada air tergenang sehingga akan membunuh jentik nyamuk sebelum tumbuh dewasa sehingga dapat meminimalkan penyebaran penyakit yang disebabkan oleh vektor nyamuk. Dosis aplikasi yang digunakan sudah menjadi rekomendasi dari Kementerian Kesehatan yaitu 10 gram bubuk abate untuk digunakan ke dalam 100 liter air.

Saat ini abate banyak digunakan sebagai pengendalian jentik nyamuk Aedes spp. namun sebenarnya dapat digunakan untuk semua jenis nyamuk seperti pada Culex spp. Nyamuk Aedes spp. berpotensi menularkan penyakit demam berdarah dengue (DBD) dan bahkan dapat menimbulkan kematian, terlebih lagi bila musim penghujan telah tiba yang membuat genangan air sehingga nyamuk Aedes spp mudah berkembang biak. Data menurut Kementerian Kesehatan bahwa jumlah penderita DBD dilaporkan mencapai 13.683 orang di seluruh Indonesia pada awal tahun 2019.(2) Tak kalah pentingnya, bahwa vektor nyamuk yang menjadi perhatian penting yaitu nyamuk Culex spp yang merupakan binatang pengganggu di sekitar masyarakat dan dapat juga menjadi media penularan penyakit seperti filariasis, St. Louis Enchepalitis, Western Enchepalitis, Jepanese Enchepalitis (3), maka peneliti akan melakukan penelitian guna membandingkan tingkat kematian jentik nyamuk Aedes spp. dengan Culex spp. melalui penggunaan abate dengan dua perlakuan yaitu ditaburkan dan dimasukkan ke dalam kertas saring. Sehingga penelitian ini mempunyai tujuan antara lain:

1. Mengidentifikasi kematian jentik nyamuk Culex spp dengan aplikasi metode abate ditaburkan

2. Mengidentifikasi kematian jentik nyamuk Culex spp dengan aplikasi metode abate dibungkus kertas saring

3. Mengidentifikasi kematian jentik nyamuk Aedes spp dengan aplikasi metode abate ditaburkan

4. Mengidentifikasi kematian jentik nyamuk Aedes spp dengan aplikasi metode abate dibungkus kertas saring 
5. Menganalisis perbedaan kematian jentik nyamuk Culex spp dengan perlakuan aplikasi metode abate dibungkus kertas saring dan ditaburkan.

6. Menganalisis perbedaan kematian jentik nyamuk Aedes spp dengan perlakuan aplikasi metode abate dibungkus kertas saring dan ditaburkan.

\section{METODE PENELITIAN}

Jenis penelitian ini adalah eksperimen semu (quasy eksperimental) yang merupakan penelitian yang menempatkan subjek pada kelompok kontrol dan kelompok kasus yang tidak dilakukan secara randomisasi (4). Penelitian dilakukan untuk melihat kematian jentik Culex spp dan Aedes spp. Rancangan penelitian tersebut dibagi dua kelompok yaitu perlakuan ditabur dan perlakuan dibungkus kertas saring dengan masing-masing menggunakan kontrol atau yang tidak diberi perlakuan. Penelitian tersebut akan diuji analisis menggunakan uji analysis of varians (Annova) untuk melihat varians waktu kematian jentik Culex spp dan jentik Aedes spp, serta analisis Probit untuk melihat probability waktu kematian jentik Culex spp dan jentik Aedes spp.

Penelitian dilakukan di Laboratorium Politeknik Kesehatan Kementerian Kesehatan Jakarta II Jurusan Kesehatan lingkungan. Dalam penelitian ini menggunakan populasi larva/jentik culex spp dan Aedes spp instar III, berukuran 4-5 mm atau 3-4 hari setelah telur menetas. Larva tersebut bercirikan duri-duri dada mulai jelas dan corong pernafasan berwarna coklat kehitaman. Larva yang digunakan sebanyak 270 ekor jentik Culex spp dan 270 ekor jentik Aedes spp yang terdiri dari :

1. Uji eksperimen I : (30 ekor $\mathrm{x} 2$ perlakuan $\mathrm{x} 4$ pengulangan $)+(30$ ekor kontrol) sehingga membutuhkan 270 ekor jentik Culex spp.

2. Uji eksperimen II : (30 ekor $\mathrm{x} 2$ perlakuan $\mathrm{x} 4$ pengulangan $)+(30$ ekor kontrol) sehingga membutuhkan 270 ekor jentik Aedes spp.

Prosedur Penelitian ini menggunakan uji eksperimen yang dilakukan dengan konversi bubuk abate 0,5 gr dalam 5 liter air buangan RT untuk percobaan jentik Culex spp dan air bersih untuk jentik Aedes spp. Uji ini dilakukan dengan 4 kali pengulangan pada perlakuan ditabur dan 4 kali pengulangan perlakuan dibungkus kertas saring dan ditambah 1 media kontrol dengan tanpa perlakuan pada masing masing jenis jentik sebagai eksperimen. 
Pada setiap perlakuan waktu dan jumlah kematian jentik nyamuk Culex spp dan Aedes spp akan dicatat setiap 10 menit dalam 1 jam pertama selanjutnya didiamkan selama 24 jam untuk melihat jumlah kematian jentik Culex spp dan Aedes spp. untuk jumlah perlakuan dan kontrol yang dilaksanakan menggunakan jumlah jentik sebanyak 270 ekor jentik Culek spp dan 270 ekor jentik Aedes spp dengan masing-masing perlakuan dan kontrol sebanyak 30 ekor jentik Culek spp serta kontrol sebanyak 30 ekor jentik Aedes spp seperti pada gambar 3.1 di bawah ini.

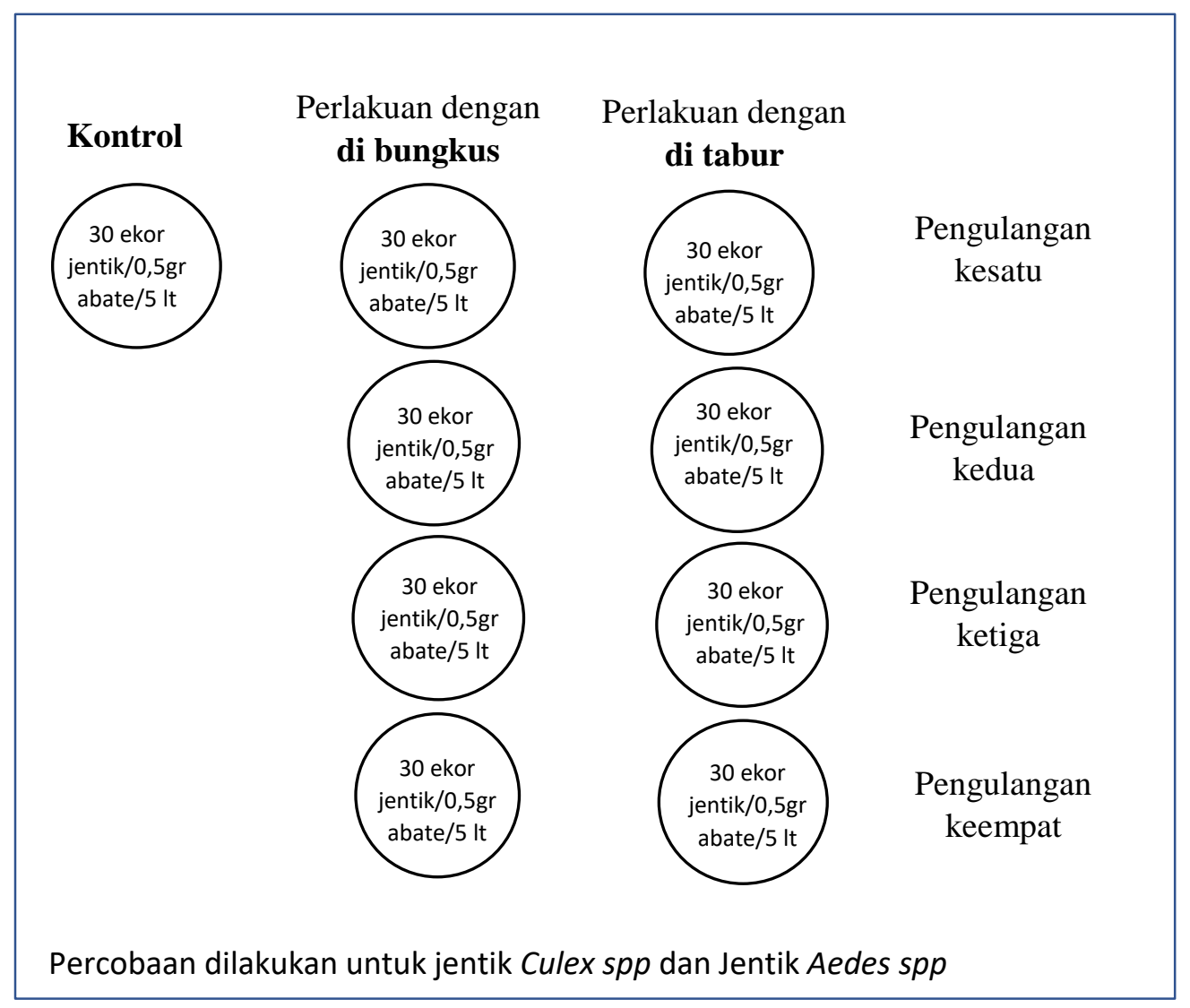

Gambar 1. Metode penelitian

\section{HASIL DAN PEMBAHASAN}

1. Kematian jentik nyamuk Culex Spp dengan ditaburkan dilihat sampai dengan 24 jam dengan dosis $10 \mathrm{~g} / 100$ liter dikatakan masih relevan digunakan karena sampai dengan 24 jam pengukuran jumlah kematian jentik dinyatakan 30 ekor jentik Culex spp mengalami kematian. 
2. Kematian jentik nyamuk Culex Spp dengan kertas saring dilihat sampai dengan 24 jam dengan dosis $10 \mathrm{~g} / 100$ liter dikatakan masih relevan digunakan karena sampai dengan 24 jam pengukuran jumlah kematian jentik dinyatakan 30 ekor jentik Culex spp mengalami kematian.

3. Kematian jentik nyamuk Aedes Spp dengan ditaburkan dilihat sampai dengan 24 jam dengan dosis $10 \mathrm{~g} / 100$ liter dikatakan masih relevan digunakan karena sampai dengan 24 jam pengukuran jumlah kematian jentik dinyatakan 30 ekor jentik Aedes spp. mengalami kematian.

4. Kematian jentik nyamuk Aedes Spp dengan kertas saring dilihat sampai dengan 24 jam dengan dosis $10 \mathrm{~g} / 100$ liter dikatakan masih relevan digunakan karena sampai dengan 24 jam pengukuran jumlah kematian jentik dinyatakan 30 ekor jentik Aedes spp mengalami kematian.

5. Berdasarkan uji anova untuk perlakuan dibungkus dan ditaburkan dengan hasil sig. adalah 0,00 atau lebih kecil dari 0,05 sehingga hasil tersebut menunjukkan bahwa tidak ada perbedaan dengan aplikasi pemberian abate dibungkus maupun ditaburkan terhadap kematian Culex Spp

6. Berdasarkan uji anova untuk perlakuan dibungkus dan ditaburkan dengan hasil sig. adalah 0,00 atau lebih kecil dari 0,05 sehingga hasil tersebut menunjukkan bahwa tidak ada perbedaan dengan aplikasi pemberian abate dibungkus maupun ditaburkan terhadap kematian Aedes Spp.

Berdasarkan hasil diatas bahwa hal ini sejalan dengan penelitian yang menyebutkan bahwa abate yang digunakan atau diaplikasikan pada masyarakat masih sangat efektif membunuh larva.(5) serta hasil penelitian menunjukkan tidak ada perbedaan untuk perlakuan penggunaan themepos/abate ditabur dan dibungkus kertas saring untuk jentik nyamuk Aedes spp maupun Culex spp

\section{SIMPULAN}

Pemberian abate dengan dosis standar nasional (1 gram/10 Liter) dalam 24 jam dengan cara ditaburkan efektif atau dapat mematikan $100 \%$ jentik nyamuk Culex spp. Pemberian abate dengan dosis standar nasional (1 gram/10 Liter) dalam 24 jam dengan cara dibungkus kertas saring efektif atau dapat mematikan $100 \%$ jentik nyamuk Culex spp. Pemberian abate 
dengan dosis standar nasional (1 gram/10 Liter) dalam 24 jam dengan cara ditaburkan efektif atau dapat mematikan $100 \%$ jentik nyamuk Aedes spp. Pemberian abate dengan dosis standar nasional (1 gram/10 Liter) dalam 24 jam dengan cara dibungkus kertas saring efektif atau dapat mematikan $100 \%$ jentik nyamuk Culex spp. Tidak ada perbedaan pemberian abate dengan dosis standar nasional (1 gram/10 Liter) dalam 24 jam dengan cara dibungkus kertas saring dengan ditabur terhadap kematian jentik Culex spp.Tidak ada perbedaan pemberian abate dengan dosis standar nasional (1 gram/10 Liter) dalam 24 jam dengan cara dibungkus kertas saring dengan ditabur terhadap kematian jentik Aedes spp.

\section{SARAN}

Pemberian abate dengan cara dibungkus kertas saring sebaiknya untuk jentik pada air menggenang seperti Aedes spp karena tidak memberikan sisa butiran pada tampungan air yang digunakan untuk aktifitas manusia. Pemberian abate untuk jentik Culex spp dengan cara dibungkus untuk air yang sedikit mengalir dan air yang menggenang dapat digunakan yang ditabur atau dibungkus.

\section{DAFTAR PUSTAKA}

1. Pambudi BC, Tarwotjo U, Hestiningsih R. Efektivitas Temephos Sebagai Larvasida pada Stadium Pupa Aedes aegypti. J Kesehat Masy Indones . 2018;6(1):385. Available from: http://ejournal3.undip.ac.id/index.php/jkm

2. Syafii M. 13.683 Kasus DBD di Indonesia dalam Sebulan, 133 Orang Meninggal. Kompas.com. 2019; Available from: https://regional.kompas.com/read/2019/01/31/14365721/13683

3. Herdiana A. Nyamuk Culex Sp Penular Penyakit Pada Manusia. Informasi Kesling. 2015. Available from: http://www.informasikesling.blogspot.com

4. Wibowo A. Metodelogi Penelitian Praktis. 1st ed. Jakarta: Rajawali Pers; 2014. 282 p.

5. Donggala BLPB, Penelitian Balitbang. Tingkat Kematian Larva Aedes Aegypti dan Aedes Albopictus Terhadap Penggunaan Abate dengan Metode Berbeda. 2017; 